\title{
ОСОБЛИВОСТІ ЗМІН ЖИРНОКИСЛОТНОГО СКЛАДУ ФОСФОЛІПІДІВ ТА СТРУКТУР ПЕЧІНКИ ПРИ РЕЗЕКЦІЇ РІЗНИХ ОБ’ЄМІВ ЇЇ ПАРЕНХІМИ
}

Вступ. Пострезекційна портальна гіпертензія призводить до структурної перебудови судин та органів басейну ворітної печінкової вени, а також фрункціонально-морфоологічних змін печінки, які при цьому вивчено недостатньо.

Мета дослідження - вивчити особливості змін жирнокислотного складу фросфроліпідів та структур печінки при резекції різних об'ємів ії паренхіми.

Методи дослідження. Біохімічними і морфологічними методами вивчено жирнокислотний склад фоосфоліпідів та структури печінки 45-ти лабораторних статевозрілих білих щурів-самців, яких поділили на 3 групи. До 1-ї (контрольної) групи входили 15 інтактних тварин, до 2-ї - 15 щурів після резекції лівої бокової частки (31,5 \% паренхіми печінки), до 3-ї - 15 тварин після видалення лівої і правої бокових часток печінки (58,1%). Евтаназію щурів здійснювали шляхом кровопускання за умов тіопенталового наркозу через 1 місяць від початку експерименту. Біохімічно визначали жирнокислотний склад деяких фросфроліпідів печінки. З печінки виготовляли гістологічні мікропрепарати. Проводили морфометрію гепатоцитів та гілок ворітної печінкової вени. Кількісні величини обробляли статистично.

Результати й обговорення. Встановлено, що видалення лівої і правої часток печінки в білих щурів призводило до пострезекційної портальної гіпертензії, виражених змін жирнокислотного складу фросфроліпідів та структур печінки. Найбільш виражені зміни виявлено в гілках ворітної печінкової вени. Встановлено кореляційні зв'язки між жирнокислотним складом фросороліпідів та структурами печінки.

Висновки. Видалення лівої і правої часток печінки в білих щурів призводить до пострезекційної портальної гіпертензії, виражених змін жирнокислотного складу фоосфоліпідів та структур печінки, які моророметрично характеризуються суттєвим зростанням розмірів гепатоцитів, їх ядер, ядерно-цитоплазматичних і стромально-паренхіматозних відношень, збільшенням відносних об'ємів пошкоджених паренхіматозних клітин, ендотеліоцитів, інфрільтративних та склеротичних процесів. Домінують структурні зміни в гілках ворітної печінкової вени.

КЛЮЧОВІ СЛОВА: резекція печінки; жирнокислотний склад фосфоліпідів; структури печінки.

ВСТУП. Резекцію печінки сьогодні нерідко виконують у хірургічних стаціонарах. Показаннями до цієї операції є доброякісні та злоякісні пухлини, метастази, травми печінки, внутрішньопечінковий холангіолітіаз, альвеолярний ехінококоз, трансплантація печінки [1-3]. Резекція великих об'ємів печінки може призводити до різних пострезекційних ускладнень: кровотечі 3 варикозно розширених вен стравоходу, шлунка, прямої кишки, асциту, спленомегалії, вторинного гіперспленізму, паренхіматозної жовтяниці, портосистемної енцесралопатії, печінкової недостатності, гепаторенального синдрому, поліорганної недостатності, портальної гіпертензії [1, 4]. Пострезекційна портальна гіпертензія спричиняє структурну перебудову судин та органів (с Л. В. Татарчук, Н. Я. Монастирська, М. С. Гнатюк, 2020. басейну ворітної печінкової вени, а також фрункціонально-структурні зміни печінки [4-6].

Мета дослідження - вивчити особливості змін жирнокислотного складу фоосфоліпідів та структур печінки при резекції різних об'ємів ії паренхіми.

МЕТОДИ ДОСЛІДЖЕННЯ. КомПЛексом біохімічних і морфологічних методів вивчено жирнокислотний склад фосороліпідів та структури печінки 45-ти лабораторних статевозрілих білих щурів-самців, яких поділили на 3 групи. До 1-ї (контрольної) групи входили 15 інтактних тварин, до 2-ї - 15 щурів після резекції лівої бокової частки (31,5\% паренхіми печінки), до 3-ї-15 тварин після видалення лівої і правої бокових часток печінки $(58,1$ \%) [6]. Евтаназію щурів здійсню- 
вали шляхом кровопускання за умов тіопенталового наркозу через 1 місяць від початку експерименту.

Жирнокислотний склад фроссроліпідів печінки визначали за методикою Й. Ф. Рівіса [7]. Вирізані шматочки печінки фріксували в $10 \%$ нейтральному розчині формаліну, проводили через етилові спирти зростаючої концентрації та поміщали у парафрін. Мікротомні зрізи товщиною 5-7 мкм після депарафрінізації забарвлювали гематоксилін-еозином, за Ван-Гізон, Маллорі, Вейгертом, толуїдиновим синім [8].

Морфометрично в печінці визначали ядерно-цитоплазматичні відношення (ЯЦВ) у гепатоцитах, стромально-паренхіматозні відношення (СПВ) у печінці та відносний об'єм пошкоджених гепатоцитів (ВОПГ) [6, 9]. У досліджуваних печінкових гілках ворітної вени визначали висоту ендотеліоцитів (ВЕ), діаметр їх ядер (ДЯЕ), ядерно-цитоплазматичні відношення (ЯЦВЕ) в цих клітинах, відносний об'єм пошкоджених ендотеліоцитів (ВОПЕ) [6, 9]. Морфометрію досліджуваних структур печінки проводили за допомогою світлового мікроскопа Olimpus BX-23 із цифровою відеокамерою і пакетом прикладних програм “Відео-тест 5,0" та "Відео-розмір 5,0”.

Проводили кореляційний аналіз між жирнокислотним складом фроссроліпідів печінки та морфометричними параметрами з визначенням коефіцієнта парної кореляції (r). Силу кореляційних зв'язків оцінювали за чотирма ступенями: сильним ( $r=0,7-0,9)$, значним $(r=0,5-0,7)$, помірним $(r=0,3-0,5)$, слабким $(r<0,3)$ [9]. Отримані кількісні показники обробляли статистично. Обробку одержаних результатів виконано у відділі системних статистичних досліджень Тернопільського національного медичного університету імені І. Я. Горбачевського МОЗ України в програмному пакеті STATISTICA. Різницю між порівнюваними величинами визначали за критеріями Стьюдента і Манна - Уїтні [10]. Дослідження та евтаназію експериментальних тварин проводили 3 дотриманням Загальних етичних принципів експериментів на тваринах, ухвалених на Першому національному конгресі з біоетики (Київ, 2001), відповідно до Європейської конвенції про захист хребетних тварин, що використовуються для дослідних та інших наукових цілей, а також Закону України "Про захист тварин від жорстокого поводження" (від 21.02.2006 р.).

РЕЗУЛЬТАТИ Й ОБГОВОРЕННЯ. ПіД час аналізу отриманих даних встановлено, що видалення 31,5 \% паренхіми печінки не призводило до виражених гемодинамічних порушень у ворітній печінковій вені. Жирнокислотний склад досліджуваних фоосфоліпідів печінки та її струк- тури при цьому суттєво не змінювалися, крім відносних об'ємів пошкоджених гепатоцитів і ендотеліоцитів, що адекватно підтверджувалося одержаними показниками (табл. 1-3). Резекція лівої і правої бокових часток печінки $(58,1 \%$ її паренхіми) спричиняла розвиток пострезекційної портальної гіпертензії, про що свідчили розширення та повнокров'я ворітної печінкової вени, брижових вен, а також вен тонкої і товстої кишок, спленомегалія, асцит [4, 6].

Жирнокислотний склад фоссфоліпідів печінки та їі структури при цьому суттєво змінювалися. Так, концентрація капринової кислоти за даних експериментальних умов статистично достовірно ( $<<0,01)$ зросла на 19,3 \%, лауринової - на 18,9 \%. При цьому з вираженою статистично достовірною різницею ( $<<0,001)$ збільшувалися також рівні пальмітинової і стеаринової кислот - на 10,4 та 8,1 \% відповідно.

Необхідно вказати, що рівень на 6,6 \% (p<0,01), а $\omega 6$ - підвищився на 8,7 \% $(p<0,001)$. Диспропорційні зміни $\omega 3$ та $\omega 6$ призводили до порушень співвідношення $\omega 3 / \omega 6$. Встановлено, що воно статистично достовірно ( $p<0,001)$ зменшилося на 14,1\%. На основі наведеного вище можна зробити висновок, що тривала пострезекційна портальна гіпертензія призводить до зміни композиції поліненасичених фосороліпідів тканин печінки, що негативно впливає на її фрункцію (табл. 1).

У 3-й групі спостережень ядерно-цитоплазматичні відношення в гепатоцитах збільшилися на $11,1 \%(p<0,001)$, що свідчило про порушення структурного клітинного гомеостазу в досліджуваних клітинах [6, 9]. При цьому стромально-паренхіматозні відношення в печінці з вираженою статистично достовірною різницею $(p<0,001)$ зросли в 1,9 раза, а відносний об'єм пошкоджених гепатоцитів збільшився в 7,46 раза (табл. 2).

Під час морфометричного вивчення досліджуваних вен встановлено, що відносний об'єм пошкоджених ендотеліоцитів у 2-й групі спостережень 3 вираженою статистично достовірною різницею $(p<0,001)$ збільшився $3(2,20 \pm 0,03)$ до $(4,60 \pm 0,06) \%$, тобто у 2,1 раза. При цьому переважали апоптично змінені клітини (табл. 3).

Інші морфометричні параметри вказаних вен у цій групі спостережень суттєво не змінювалися порівняно 3 аналогічними контрольними показниками.

Видалення лівої і правої бокових часток печінки призводило до пострезекційної портальної гіпертензії та виражених змін досліджуваних морфометричних параметрів вен. Так, висота ендотеліоцитів у гілках ворітної печінкової вени при цьому статистично достовірно ( $\mathrm{p}<0,001)$ зменшилася $3(6,16 \pm 0,05)$ до $(5,32 \pm 0,04)$ мкм, 
Таблиця 1 - Зміни жирнокислотного складу фосфоліпідів печінки при резекції різних об'ємів

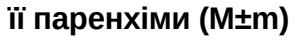

\begin{tabular}{|c|c|c|c|}
\hline \multirow{2}{*}{ Жирна кислота, код } & \multicolumn{3}{|c|}{ Г Група спостереження } \\
\hline & 1-ша & 2-га & 3-тя \\
\hline Капринова 8:0 & $0,145 \pm 0,003$ & $0,150 \pm 0,004$ & $0,173 \pm 0,005^{\star \star}$ \\
\hline Лауринова 12:0 & $0,286 \pm 0,003$ & $0,290 \pm 0,003$ & $0,340 \pm 0,006^{\star \star \star}$ \\
\hline Пальмітинова 16:0 & $7,26 \pm 0,07$ & $7,30 \pm 0,09$ & 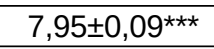 \\
\hline Стеаринова 18:0 & $8,30 \pm 0,09$ & $8,32 \pm 0,06$ & $8,97 \pm 0,12^{\star \star}$ \\
\hline Ліноленова 18:3 & $7,65 \pm 0,09$ & $7,72 \pm 0,09$ & $7,11 \pm 0,07^{\star \star}$ \\
\hline$\omega 3$ & $27,10 \pm 0,30$ & $27,38 \pm 0,33$ & $25,30 \pm 0,27^{\star \star}$ \\
\hline$\omega 6$ & $29,90 \pm 0,33$ & $30,18 \pm 0,30$ & $32,50 \pm 0,33^{\star \star \star}$ \\
\hline$\omega 3 / \omega 6$ & $0,906 \pm 0,009$ & $0,908 \pm 0,012$ & $0,778 \pm 0,006^{\star \star \star}$ \\
\hline
\end{tabular}

Примітка. ** - p<0,01; *** - p<0,001 порівняно з 1-ю групою.

Таблиця 2 - Морфометрична характеристика печінки експериментальних тварин (M士m)

\begin{tabular}{||l|c|c|c|}
\hline \multirow{2}{*}{ Показник } & \multicolumn{3}{|c||}{ Група спостереження } \\
\cline { 2 - 4 } & 1-ша & 2-га & 3-тя \\
\hline ЯЦВ & $0,189 \pm 0,004$ & $0,192 \pm 0,005$ & $0,210 \pm 0,004^{\star *}$ \\
\hline ВПВ & $0,194 \pm 0,006$ & $0,230 \pm 0,009^{\star}$ & $0,370 \pm 0,015^{\text {*** }}$ \\
\hline \hline
\end{tabular}

Примітка. * $-p<0,05 ;$ ** $-p<0,01 ;$ *** $-p<0,001$ порівняно 3 1-ю групою.

Таблиця 3 - Морфометрична характеристика ендотеліоцитів гілок ворітної печінкової вени (M士m)

\begin{tabular}{|c|c|c|c|}
\hline \multirow{2}{*}{ Показник } & \multicolumn{3}{|c|}{ Група спостереження } \\
\hline & 1-ша & 2-га & 3-тя \\
\hline BE, мкM & $6,16 \pm 0,05$ & $6,18 \pm 0,06$ & $5,32 \pm 0,04^{\star \star \star}$ \\
\hline ДЯЕ, мкм & $4,40 \pm 0,03$ & $4,37 \pm 0,04$ & $2,05 \pm 0,02^{\star \star \star}$ \\
\hline ЯЦВЕ & $0,510 \pm 0,006$ & $0,505 \pm 0,006$ & $0,248 \pm 0,003^{\star \star \star}$ \\
\hline ВОПЕ, \% & $2,20 \pm 0,03$ & $4,60 \pm 0,06^{\star \star \star}$ & $34,10 \pm 0,36^{\star \star \star}$ \\
\hline
\end{tabular}

Примітка. *** - p<0,001 порівняно з 1-ю групою.

тобто на 13,6 \%, діаметр їх ядер знизився на $53,4$ \% ( $<<0,001)$. Виражено змінювались ядерно-цитоплазматичні відношення у досліджуваних клітинах. Так, у контрольних спостереженнях даний морфометричний показник дорівнював 0,510 0,006, а у 3-й групі спостережень $0,248 \pm 0,003$. Між наведеними морфометричними параметрами встановлено статистично достовірну різницю ( $<<0,001)$. При цьому останній кількісний морфологічний показник виявився меншим за попередній на 51,3 \%. Виражено змінився за даних експериментальних умов відносний об'єм пошкоджених ендотеліоцитів зріс у 15,5 раза ( $<<0,001)$. Зниження діаметра ядра та ядерно-цитоплазматичних відношень в ендотеліоцитах досліджуваних вен вказувало на виснаження і зменшення адаптаційних резервів ядерних структур при змодельованій патології. Наведене вище підтверджувалося зниженням співвідношення $\omega 3 / \omega 6$, яке $€$ несприятливим прогностичним критерієм модифікації структурно-срункціональної організації клітинних та субклітинних біомембран [11].
Під час кореляційного аналізу було з'ясовано, що зв'язки між жирнокислотним складом фосороліпідів печінки та досліджуваними морфометричними параметрами посилювались у тварин 3-ї групи. Встановлено наявність сильних позитивних кореляційних зв'язків між рівнем $\omega 6$ та ВОПЕ $(r=+0,76 \pm 0,02)$. Між ВОПЕ і концентрацією $\omega 3$ існував аналогічної сили від'ємний зв'язок ( $r=-0,79 \pm 0,02)$. Дещо більшої сили позитивні кореляційні зв'язки виявлено між співвідношенням $\omega 3 / \omega 6$ та ВОПЕ і ВОПГ $(r=+0,83-0,85)$. Коеоріцієнт кореляції між ядерно-цитоплазматичними відношеннями в гепатоцитах тварин 3-ї групи і рівнем $\omega 6$ дорівнював 0,58 0,03 (значний зв'язок), між $\omega 6$ та ЯЦВЕ $-0,81 \pm 0,02$ (сильний від'ємний зв'язок). Наведене вище свідчить про наявність зв'язків між структурними змінами печінки та жирнокислотним складом ії фроссроліпідів за умов пострезекційної портальної гіпертензії.

Під час світлооптичного дослідження гістологічних мікропрепаратів печінки встановлено, що структурні зміни у досліджуваному органі 
спостерігалися переважно у тварин 3-ї групи (резекція 58,1 \% паренхіми печінки). При цьому відзначали виражене розширення та повнокров'я венозних судин печінки, нерівномірність і десормацію їх просвіту. Відмічали також перивазальний набряк, який місцями звужував та деформував досліджувані судини. Проявлялися і дистрофрія ендотеліоцитів та місцями десквамація останніх. Деякі ендотеліоцити були з явищами набряку, межі між ними не чіткі, частина вказаних клітин дистрофрічно та некробіотично змінена. Розміри гепатоцитів та їх ядер збільшені, спостерігали осередки їх набряку, дистросрії і некробіозу. Відзначали набряк строми, її розростання і вогнищеві стромальні гістіоцитарні інфрільтрати. Більшість венозних судин розширені, переповнені фрорменими елементами крові, з явищами стазу, тромбозу, що свідчило про виражене порушення їх дренажної срункції [3]. Венозний застій у досліджуваних судинах призводив до посилення гіпоксії, дистрофрії і некрозів ендотеліоцитів, гепатоцитів [5], стро- мальних структур, інфрільтративних та склеротичних процесів.

ВИСНОВКИ. Видалення лівої і правої часток печінки в білих щурів призводить до пострезекційної портальної гіпертензії, виражених змін жирнокислотного складу фоссроліпідів та структур печінки, які морфометрично характеризуються суттєвим зростанням розмірів гепатоцитів, їх ядер, ядерно-цитоплазматичних і стромально-паренхіматозних відношень, збільшенням відносних об'ємів пошкоджених паренхіматозних клітин, ендотеліоцитів, інфрільтративних та склеротичних процесів. Домінують структурні зміни в гілках ворітної печінкової вени.

Перспективи подальших досліджень. Детальне всестороннє дослідження структурно-фрункціональних змін печінки при резекції різних об'ємів ії паренхіми дозволить істотно розширити своєчасну діагностику, корекцію та профрілактику пострезекційних ускладнень.

\section{СПИСОК ЛІТЕРАТУРИ}

1. Особливості виконання обширних резекцій печінки з урахуванням профілактики післяопераційних ускладнень / І. В. Волченко, В.М.Лихман, Д. І. Скорий, А. М. Шевченко // Харк. хірург. шк. - 2016. - № 3 (78). C. $35-39$.

2. Хірургічне лікування вогнищевого ураження печінки: аналіз результатів та перспективи / О. І. Дронов, С. В. Земсков, Ю. П. Бакунець, П. П. Бакунець // Клініч. хірургія. - 2016. - № 1. - С. 28-31.

3. Досвід виконання резекцій печінки у хворих на метастатичний колоректальний рак / О. О. Колеснік, А. А. Бурлака, А. В. Лукашенко [та ін.] // Клініч. онкологія. - 2015. - № 2 (18). - С. 8-13.

4. Дзигал О. Ф. Формування полісиндромної недостатності у хворих на цироз печінки з портальною гіпертензією / О. Ф. Дзигал // Вісн. наук. дослідж. 2017. - № 2. - C. 88-92.

5. Гарбузенко Д. В. Морфоорункциональная перестройка печеночного сосудистого русла в патогенезе портальной гипертензии при циррозе печени I Д. В. Гарбузенко // Тер. арх. - 2014. - № 86 (2). C. 90-95.

6. Гнатюк М. С. Морсометрична оцінка особливостей ремоделювання структур дванадцятипалої кишки при резекції різних об'ємів печінки / М. С. Гна- тюк, Л. В. Татарчук, О. Б. Ясіновський // Наук. вісн. Ужгород. ун-ту. Серія “Медицина”. - 2016. Вип. 1 (53). - С. 92-95.

7. Рівіс Й. Ф. Кількісні хроматографрічні методи визначення окремих ліпідів і жирних кислот у біологічному матеріалі / Й. Ф. Рівіс, Р. С. Федорук. - Львів, 2010. - 109 c.

8. Горальський Л. П. Основи гістологічної техніки і морфоорункціональні методи досліджень у нормі і при патології / Л. П. Горальський, В. Т. Хомич, О. І. Кононський. - Житомир : Полісся, 2011. - 288 с.

9. Автандилов Г. Г. Основы количественной патологии / Г. Г. Автандилов. - М. : Медицина, 2002. - 240 с.

10. Гржибовский А. И. Сравнение количественных данных двух парных выборок с использованием программного обеспечения Statistica и SPSS: параметрические и непараметрические критерии I А. И. Гржибовский, О.В.Иванов, М. А. Горбатова // Наука и здравоохранение. - 2016. - 3. - С. 5-25.

11. Feng R.T. Molecular mechanism of low doze ionizing radiation in order to control bionegative effects to the organism and related human diseases / R. T. Feng, K. I. Weng // International Journal of Radiation Biology. 2015. - 91. - P. 13-27. 


\section{REFERENCES}

1. Volchenko, I.V., Lykhman, V.M., Skoryy, D.I., \& Shevchenko, A.M. (2016). Osoblyvosti vykonannia obshchyrnykh rezektsii pechinky z urakhuvanniam profilaktyky pisliaoperatsiinykh uskladnen [Peculiarities of performing extensive liver resections taking into account the prevention of postoperative complications]. Kharkivska khirurhichna shkola - Kharkiv Surgical School, 3 (78), 35-39 [in Ukrainian].

2. Dronov, O.I., Zemskov, S.V., Bakunets, Y.P., \& Bakunets, P.P. (2016). Khirurgicheskoye lecheniye ochagovogo porazheniya pecheni analiz rezultatov i perspektivy [Surgical treatment of focal liver disease: analysis of results and prospects]. Klinicheskaya khirurgiya Clinical Surgery, 1, 28-31 [in Ukrainian].

3. Kolesnik, O.O., Burlaka, A.A., Lukashenko, A.V., \& Pryymak, V.V. (2015). Dosvid vykonannia rezektsii pechinky na metastatychnyi kolorektalnyi rak [Experience of liver resection for metastatic colorectal cancer]. Klinichna onkolohiia - Clinical Oncology, 2 (8), 8-13 [in Ukrainian].

4. Dzyhal, O.F. (2017). Formuvannia polisyndromnoi nedostatnosti khvorykh na tsyroz pechinky z portalnoiu hipertenziieiu [Formation of polysyndromic insufficiency of patients with liver cirrhosis with portal hypertension]. Visnyk naukovykh doslidzhen - Bulletin of Scientific Research, 2, 88-92 [in Ukrainian].

5. Garbuzenko, D.V. (2014). Morfofunktsionanaya perestroyka pechenochnogo sosudistogo rusla $v$ patogeneze portalnoy gipertenzii pri tsirroze pecheni [Morphofunctional rearrangement of the hepatic vasculature in the pathogenesis of portal hypertension in liver cirrhosis]. Ter. Arkh. - Ter. Arch., 86 (2), 90-95 [in Russian].

6. Hnatiuk, M.S., Tatarchuk, L.V., \& Yasinovskyy, O.B. (2016). Morfometrychna otsinka osoblyvostei remodeliuvannia struktur dvanadtsiatypaloi kyshky pry resektsii riznykh obiemiv pechinky [Morphometric evaluation of the features of remodeling of duodenal structures during resection of different volumes of the liver]. Naukovyi visnyk Uzhhorodskoho universytetu. Seriia "Medytsyna" Scientific Herald of Uzhhorod University. Series "Medicine", 1 (49), 3-5 [in Ukrainian].

7. Rivis, Y.F., \& Fedoruk, R.S. (2010). Kilkisni khromatohrafichni metody vyznachennia okremykh lipidiv s zhyrnykh kyslot u biolohichnomu materiali [Quantitative chromatographic methods for the determination of individual lipids and fatty acids in biological material]. Lviv [in Ukrainian].

8. Horalsky, L.P., Khomych, V.T., \& Kononsky, O.I. (2011). Osnovy histolohichnoi tekhniky i morfofunktsionalni metody doslidzhen u normi i pry patolohii [Fundamentals of histological technique and morphofunctional research methods in norm and in pathology]. Zhytomyr: Polissia [in Ukrainian].

9. Avtadnilov, G.G. (2002). Osnovy kolichestvennoy patologicheskoy anatomii [Basis of quantitative pathological anatomy]. Moscow: Meditsyna [in Russian].

10. Grzhibovskiy, A.I., Ivanov, O.V., \& Gorbatova, M.A. (2016). Sravneniye kolichestvennykh dannykh dvukh parnykh vyborok $s$ vnedreniyem programmnogo obespecheniya Statistica i SPSS: parametricheskiye i neparametricheskiye kriterii [Comparison of quantitative data of two paired samples using Statistica and SPSS software: parametric and nonparametric criteria]. Nauka $i$ zdravookhraneniye - Science and Healthcare, 3, 5-25 [in Russian].

11. Feng, R.T., \& Weng, K.I. (2015). Molecular mechanism of low doze ionizing radiation in order to control bionegative effects to the organism and related human diseases. International Journal of Radiation Biology, 91, 13-27.

Л. В. Татарчук, Н. Я. Монастырская, М. С. Гнатюк ТЕРНОПОЛЬСКИЙ НАЦИОНАЛЬНЫЙ МЕДИЦИНСКИЙ УНИВЕРСИТЕТ ИМЕНИ И. Я. ГОРБАЧЕВСКОГО МОЗ УКРАИНЫ

\section{ОСОБЕННОСТИ ИЗМЕНЕНИЙ ЖИРНОКИСЛОТНОГО СОСТАВА ФОСФОЛИПИДОВ И СТРУКТУР ПЕЧЕНИ ПРИ РЕЗЕКЦИИ РАЗНЫХ ОБЪЕМОВ ЕЕ ПАРЕНХИМЫ}

\section{Резюме}

Вступление. Пострезекционная портальная гипертензия приводит к структурной перестройке сосудов и органов бассейна воротной печеночной вены, а также фрункционально-морфологическим изменениям печени, которые при этом изучено недостаточно.

Цель исследования - изучить особенности изменений жирнокислотного состава фросфолипидов и структур печени при резекции различных объемов ее паренхимы.

Методы исследования. Биохимическими и морфологическими методами изучено жирнокислотный состав фросфолипидов и структуры печени 45-ти лабораторных половозрелых белых крыс-самцов, которых разделили на 3 группы. В 1-ю (контрольную) группу входили 15 интактных животных, во 2-ю 15 крыс после резекции левой боковой доли (31,5\% паренхимы печени), в 3-ю - 15 животных после удаления левой и правой боковых долей печени (58,1%). Эвтаназию крыс осуществляли путем кровопускания в условиях тиопенталового наркоза через 1 месяц после начала эксперимента. Биохимически определяли жирнокислотный состав некоторых фросфролипидов печени. С печени изготавливали гистологические 
микропрепараты. Проводили морфометрию гепатоцитов и ветвей воротной печеночной вены. Количественные величины обрабатывали статистически.

Результаты и обсуждение. Установлено, что удаление левой и правой долей печени у белых крыс приводило к пострезекционной портальной гипертензии, выраженным изменениям жирнокислотного состава фросфолипидов и структур печени. Наиболее выраженные изменения выявлено в ветвях воротной печеночной вены. Установлено корреляционные связи между жирнокислотным составом фросоролипидов и структурами печени.

Выводы. Удаление левой и правой долей печени у белых крыс приводит к пострезекционной портальной гипертензии, выраженным изменениям жирнокислотного состава фросфролипидов и структур печени, которые морфометрически характеризуются существенным ростом размеров гепатоцитов, их ядер, ядерно-цитоплазматических и стромально-паренхиматозных отношений, увеличением относительных объемов поврежденных паренхиматозных клеток, эндотелиоцитов, инфрильтративных и склеротических процессов. Доминируют структурные изменения в ветвях воротной печеночной вены.

КЛЮЧЕВЫЕ СЛОВА: резекция печени; жирнокислотный состав фосффолипидов; структуры печени.

L. V. Tatarchuk, N. Ya. Monastyryska, M. S. Hnatiuk I. HORBACHEVSKY TERNOPIL NATIONAL MEDICAL UNIVERSITY

\section{PECULIARITIES OF CHANGES IN FATTY ACID COMPOSITION OF PHOSPHOLIPIDS AND LIVER STRUCTURES AT RESECTION OF DIFFERENT VOLUMES OF ITS PARENCHYMA}

\section{Summary}

Introduction. Postresection portal hypertension leads to structural rearrangement of vessels and organs of the portal hepatic vein, as well as functional and morphological changes of the liver, which are insufficiently studied.

The aim of the study - to learn the features of changes in the fatty acid composition of phospholipids and liver structures at resection of different volumes of its parenchyma.

Research Methods. Biochemical and morphological methods were used to study the fatty acid composition of liver phospholipids and its structure in 45 laboratory adult white male rats, which were divided into 3 groups. Group 1 had 15 intact animals (control), 2 - 15 rats after resection of the left lateral lobe $-31.5 \%$ of the liver parenchyma, $3-15$ animals after removal of the right and left lateral lobes of the liver (58.1\%). Euthanasia of rats was performed by bloodletting under conditions of thiopental anesthesia 1 month after the start of the experiment. Biochemically determined the fatty acid composition of some phospholipids of the liver. Histological micronutrients were made from the liver. Morphometry of hepatocytes and branches of the hepatic portal vein was performed. Quantitative values were processed statistically.

Results and Discussion. It was found that the removal of the left and right lobes of the liver in white rats leads to postresection portal hypertension, pronounced changes in the fatty acid composition of phospholipids and liver structures. The most pronounced changes were found in the branches of the portal hepatic vein. Correlations between the fatty acid composition of phospholipids and liver structures have been revealed.

Conclusions. Removal of the left and right lobes of liver in white rats leads to postresection portal hypertension, marked changes in fatty acid composition of phospholipids and liver structures, which are morphometrically characterized by a significant increase in hepatocytes, their nuclei, nucleo-cytoplasmic and stromal parenchymal relation relative volume damage parenchymal cells, endotheliocytes, infiltrative and sclerotic processes. Structural changes in the branches of the hepatic portal vein dominated.

KEY WORDS: liver resection; fatty acid composition of phospholipids; liver structure.

Отримано 02.07.20

Адреса для листування: М. С. Гнатюк, Тернопільський національний медичний університет імені І. Я. Горбачевського моз України, майдан Волі, 1, Тернопіль, 46001, Україна, e-mail: hnatjuk@tdmu.edu.ua. 